\title{
On the Cultivation of College Students' English Self-regulated Learning Ability
}

\author{
Zhen Zhou \\ Foreign Languages College, Nanchang Normal University, \\ Nanchang, Jiangxi, China, 330032 \\ zoye100@sina.com
}

Keywords: Self-regulated learning ability; College students; Learning strategy; Motivation; Self-efficacy.

\begin{abstract}
As the teaching concept of "student-centered" is widely advocated, it has attracted great attention in the educational field. But at present, the self-regulated learning awareness and ability of college students is very weak, which should call our great attention. In order to change the situation, the English teachers should assist college students to enhance their self-regulated learning ability through the following ways, establishing a relaxing classroom atmosphere, cultivating students' self-regulated learning awareness, creating good self-regulated learning environment, transforming teachers' and students' traditional roles, motivating students' learning desire, intensify the guidance of learning strategy, and enhance students' English learning self-efficacy. The article aims to boost college students' self-regulated learning awareness and improve their self-regulated learning ability, ultimately enable students to learn how to learn independently and efficiently, and facilitate English teaching and learning, so as to enhance English teaching quality.
\end{abstract}

\section{Introduction}

The learner-centered teaching mode, which attaches great importance to the core status of learners, is opposite to the traditional teacher-centered model. The English teaching should take learners' realities into consideration. The task of teachers is to try their best to supply and create some real language environment to help learners learn or guide students to learn, help them to express their own thoughts and feelings. The learner-centered teaching is a total new concept, which becomes a consensus for educational researchers and teachers to cultivate students' self-regulated learning ability in the recent years $[1,2,3,4]$.

The concept of "self-regulated learning" originated from the debates on the development of life-long learning skills and the development of independent thinkers, both of which dated back to the 1960s. As early as in 1980s, Holec began his report to the Council of Europe with a description of the social and ideological context within which ideas of autonomy in learning emerged [5]. From then on, the development of autonomous learning programs has spread worldwide. Holec points out the English teaching should have two goals, one is to aid students to acquire language and communicative skills; the other is to help them to obtain self-regulated leaning ability [5]. Benson and Voller put forward that self-regulated learning means students learn to study on their own, and are able to grasp a series of skills such as self deterring goals, selecting learning material, assessing learning processes and results, in which the teacher plays a guiding and facilitating role [6, 7]. The self-regulated learning experiments have proven that self-regulated learning is an effective method for East Asian learners. Especially in China, autonomous learning has been enjoying increasing attention in recent years, and many educators and researchers have conducted their research on autonomous in foreign language learning $[8,9,10]$. 


\section{The Theoretical Foundation}

The main theoretical foundation of self-regulated learning is social cognitive theory, constructive learning theory and humanistic psychology. These theories all attach great importance to placing students in the center of the language teaching.

Social Cognitive Theory. The social cognitive theory puts forward that behaviors are largely regulated through cognitive processes. And it emphasizes self-regulated capability and self-reflective capability, especially self-efficacy during the cognitive processes. Self-efficacy, as a part of self-reflective capabilities, influences motivation, behaviors and achievement of learners. Bandura proposes that self-regulation is an internal control mechanism that governs what behavior is performed, and is extremely important because it allows the gradual substitution of internal controls for external controls of the behavior [11].

Constructive Learning Theory. The Constructive learning theory stresses initiatives, sociality and context and it claims that learning is an active process of constructing rather than acquiring knowledge passively. It requires learners to learn through higher-order thinking and problem solving. Learners need to analyze, integrate, assess and apply the knowledge they have learned to solve many complex and uncertain questions. Besides, learners are the masters of learning activity, and they should self-regulate and reflect. The theory believes each student has his own way to understand the different aspects of things.

The Humanistic Psychology. The humanistic psychology theory stresses the importance of self-concept and affective factors in adults' learning process, and highlights the uniqueness of human beings and claim that man is a free creature with ideals and great potentials. The humanistic theory emphasizes the importance of the learner and places the individual's thoughts, feelings and emotions at the forefront of all human development. Besides, they think that human's behavior is mainly controlled by self-awareness and if we want to get a all-round knowledge of human's behavior, we must consider that everyone has a basic need pointing to his self-development.

\section{The Realistic Situation}

At present, it is found out that college students lack in self-regulated learning awareness and ability [12], and in the college English teaching; there are a big gap and individual differences among students, which requires students to carry out some related practice of listening, speaking, reading, writing and translating. The advanced English learners have a set of effective self-regulated learning methods; while backward learners are rather dependent on their teachers and not able to grasp suitable learning strategies and can not achieve their learning objectives. The success of college English teaching lies largely in the self-regulated learning activities after class as a Chinese saying goes, teaching students the skill to fish can last for a life, while feeding them fish merely sustain a day. Thereby, cultivating students' self-regulated learning ability is an important guarantee of success of college English teaching.

\section{The Characteristics of Self-regulated Study}

Initiative. Self-regulated learning means that students are able to study on their own actively and autonomously, and are able to manage and control their own learning activities rather than passive learning by outer force and demand.

Efficiency. The students with self-regulated learning ability can try their best to coordinate the functions of all factors in their own learning system, and are able to make some appropriate accommodations to all steps in order to give full play to its function.

Relative Independence. Self-regulated learning demands that learners are able to escape from depending from the teacher and others in the whole process of learning, and they can make choices and control on every aspect of study, and carry out learning activities on their own. But the 
independence is merely relative; students can not completely be devoiced from the guidance and assistance from teachers and others. Therefore, self-regulated learning has its own independent respective, but also has its reliant area.

\section{The Ways to Enhance Students' Self-regulated Learning Ability}

The self-regulated learning ability is one of the important factors that students learn English successfully and it is the essential ability students should possess and master. The English teachers can foster students' self-regulated learning ability from the following ways.

Cultivating Students' Self-regulated Learning Awareness. As learners have no inherent ability of self-control and self-decision, especially Chinese college students growing up in the traditional culture which emphasizes conforming to authority unconditionally, intend to rely on others' help, rather than they take learning actions on their own. Therefore, the teacher should cultivate students' self-regulated learning awareness. On the one hand, the teacher should know well about students' self-regulated learning situation through various ways, such as questionnaires, survey, chatting, interviewing, try to help students be clear about their own learning goal, cognitive style, learning demand, their favorite and suitable strategies, then help students decide and set their suitable goal. On the other hand, the teacher should guide students to learn to make learning plans, implement learning plans, self-control, self-regulate and self-assessment. Only if students' self-regulated learning ability is raised, can they form good learning habit and enhance their self-regulated learning ability.

Establishing a Relaxing Classroom Atmosphere. Language acquisition does not occur unless learners are relaxed and have desire to learn. Teachers should create a relaxing learning atmosphere where learners will be involved in the classroom activities with their whole heart. Under a relaxing classroom atmosphere, students can explore alternative solutions to the problems and initiate appropriate learning activities in the class through independent action. It is crucial for the teacher to establish a good relationship with students, supporting and guiding them in their learning process. When the teacher does not act as an authority but a promoter, facilitator, consultant, and coordinator to provide encouragements, praise, instruction, feedback, reinforcement and aid for learners, a good teacher-student relationship is formed. Good teacher-student relationship and student-student relationship would be conducive to creating a good self-regulated learning atmosphere.

Creating Good Self-regulated Learning Environment. The effective implementation of the students' self-regulated learning can not be separated from a good self-regulated learning time and space environment. At present, the courses in many colleges and universities are very full, resulting in shortage of students' after-class time. Based on this, the teacher can design some appropriate tasks for students to explore actively in class. After class, students should learn how to manage their time, make full use of finite after-class time in studying. Besides, the school should also supply good study facilities and environment, offer abundant quiet self-study classrooms, open free web self-regulated learning center, supply ample study resources and equip specialized professional tutor teachers for students' self-regulated study assistance.

Transforming the Traditional Roles of Teachers and Students. For a long time, the teacher dominates the whole class, the class is teacher-centered and the teacher feeds knowledge to student's mouth so carefully and devotedly. In this way, students' self-regulated learning ability is neglected greatly and their learning desire is killed as well, which does harm to students' sustainable development. Nowadays, as everything is changing so fast, this is an information explosion era, education attaches great importance to people's whole-life learning, social learning, and the ability of learning to learn. Therefore, the teacher should become students' leader, guide, facilitator and illuminator. Students should not be passive receivers of external stimuli or knowledge containers any more. They should be able to study actively and good at making use of learning resources, processing information, constructing their own knowledge system actively and initially and they 
can manage their own study relaxingly, happily and actively.

Teachers' Support. In the process of cultivating students' self-regulated learning ability, learners need the support of their social relations, especially their teachers, psychological-social and technological support. Psychological-social support refers to caring for, eliciting and guiding learners and cultivating learners' self-reliance awareness; the technological support helping learners to make plans, implement and assess the requiring skills and knowledge. The teachers must give students selfless and patient help, cultivating students' self-regulated learning ability.

Motivating Students' Learning Desire. Motivation is the driving force of learning, is an important factor influencing learning behavior and learning efficiency, which is an essential condition in the learning process. At present, the motivation of college students' is very low, most of which are instrumental motivation. If the teacher wants to enhance students' motivation level, in theory, the teacher should guide students in the aspect of learning motivation idea and let students have clear, strong motivation; in practice, the teacher should employ various, interesting, dynamic and flexible teaching methods, design adequate learning tasks, to stimulate students' learning interest. The teacher should always care about and encourage students, appreciate students merits more, stimulate more external motivation of students, and enable students to transfer the external motivation to internal motivation.

Intensify the Guidance of Learning Strategy. Correct use of learning strategies is the fundamental guarantee of students' self-regulated learning, but students' self-regulated learning sometimes is carried out without teacher's guidance and assistance. Intensifying guidance and cultivating students' learning strategy using ability should put meta-cognitive learning strategies and social affective strategy first, as most students are weak in the strategy use of these two types [12]. The teacher can use the learning strategy training model-five step framework: preparation-presentation-practice-evaluation-extension to train students and make students know their strategy use condition and enhance their strategy using ability [13].

Enhance Students' English Learning Self-efficacy. Self-efficacy refers to the people's expectation of executing any particular task successfully, which influences individual behavior. The teacher should treat students patiently and positively, and should give students encouragement and positive expectation whether students make success or not. The teacher should also set appropriate teaching objectives practically, let students participate in class activities actively, make students display their ability freely, enable students to experience more success, and make every students have some sense of success. The teacher can make collective interference and individual psychological interference centering on a certain student; the teacher can organize some interaction activities such as: communication, discussion as well. Students should also learn positive self-intensification and self-attribution, lower their learning anxiety and frustration, and heighten their self-efficacy level, ultimately enhance their self-regulated learning ability.

\section{Conclusion}

The nature and law of language learning require college students to have a certain level of self-regulated learning ability. The English teachers can help college students enhance their self-regulated learning abilities through the following ways, establishing a relaxing classroom atmosphere, cultivating students' self-regulated learning awareness, creating good self-regulated learning environment, transforming teachers' and students' traditional roles, motivating students' learning desire, intensify the guidance of learning strategy, and enhance students' English learning self-efficacy.

\section{References}

[1] Gardner, David, and Lindsay Miller. Establishing self-access: from theory to practice. Shanghai: Shanghai Foreign Language Education Press. 2002. 
[2] Dickinson, L. Self-instruction in language learning. Cambridge: Cambridge University Press, 1987.

[3] Wenden, A. Learner strategies for learner autonomy: planning and implementing learner training for language learners. Hertfordshire: Prentice-Hall International, 1991.

[4] Little, D. Learner autonomy: definitions, issues and problems. Dublin: Authentik, 1991.

[5] Holec, H. Autonomy and foreign language learning. Oxford: Pergamon Press, 1981.

[6] Benson, Phil, and Peter, Voller. Eds. Autonomy and independence in language learning. London: Longman, 1997.

[7] Benson, Phil. Teaching and researching autonomy in language learning. Beijing: Foreign Language Teaching and Research Press. 2005.

[8] Bandura, Albert. Social foundations of thought and action: a social cognitive theory. Englewood Cliff, NJ: Prentice Hall, 1986.

[9] Zhiru Wang, Yunyun Zhou, Hong Wu. The dynamic research of college students' English autonomous learning ability in the academic learning transition period, J. Foreign Language World. 2015, 167(2): 25-32.

[10]Lilan Lin, The scale compiling and testing of college students' English autonomous learning ability based on three-dimension concept, J. Foreign Language World. 2013, (4): 73-80.

[11]Banban Li, Jingfen Xu. Achievement goals orientation and autonomous English learning ability: the mediating role of self-efficacy, J. Chinese Foreign Language. 2014, 11(3):60-68.

[12]Zhen Zhou. The investigation of English self-regulated study ability of college students, J. 2016, 37(2): 109-112.

[13]O’Malley, J.M. \& Chamot, A.U. Learning strategies in second language acquisition. London: Cam, 1990. 